\title{
THE CULTURAL VALUES OF THE BULANGAN LONDONG SEMBANGAN SUKE BARATA RITUAL OF THE INDIGENOUS PEOPLE OF TORAJA
}

\section{NILAI BUDAYA RITUAL BULANGAN LONDONG SEMBANGAN SUKE BARATA MASYARAKAT ADAT TORAJA}

\author{
Markus Deli Girik Allo', Nilma Taula'bi' ${ }^{1}$, Elim Trika Sudarsi ${ }^{3}$ \\ Eka Prabawati Rum ${ }^{4}$ \\ ${ }^{1,2,3}$ Universitas Kristen Indonesia Toraja, Indonesia \\ Jl. Nusantara No.12 Makale \\ ${ }^{4}$ Universitas Muhammadiyah Makassar \\ Jl. Sultan Alauddin No.259 Makassar, Indonesia \\ 1,2,3,4 e-mail: jesuitzjoseph@yahoo.com, nilma@ukitoraja.ac.id, \\ elimtrikasudarsih@ukitoraja.ac.id, eprabawatirum@gmail.com
}

DOI: $10.30959 /$ patanjala.v13i2.798

\begin{abstract}
The purpose of this study was to investigate the cultural values in the ritual of Bulangan Londong Sembangan Suke Barata as part of the Toraja indigenous people life. The research method used in this study is a qualitative method. Meanwhile, the respondents involved in this study include culturist, linguists, and the Toraja community. The research instruments used in this study were document files, interviews with the subjects, and observations using a video recorder that recorded the ritual process of Bulangan Londong Sembangan Suke Barata. The data analysis technique in this study includes three main steps, namely data reduction, data presentation, and drawing conclusions. The results showed that the cultural values contained in the rituals of the Bulang Londong Sembangan Suke Barata were 'Manuk' which symbolized the value of the work ethic, 'Ussembang Suke Barata' which represented the religious value of bamboo slashed by 'Mina', and 'Kayunan Londong' which personifies the leader's patriotic value.
\end{abstract}

Keywords: cultural values, bulangan londong sembangan suke barata ritual, indigenous people of Toraja.

\section{Abstrak}

Tujuan dari penelitian ini adalah untuk menyelidiki nilai-nilai budaya dari ritual bulangan londong sembangan suke barata dari masyarakat adat Toraja. Penelitian ini menggunakan metode kualitatif. Responden penelitian ini adalah budayawan, ahli bahasa, dan komunitas Toraja. Instrumen penelitian yang digunakan adalah file dokumen, wawancara dengan subjek, dan pengamatan dengan menggunakan perekam video pada ritual bulangan londong sembangan suke barata. Teknik analisis data mencakup tiga langkah utama, pengurangan data, presentasi data, dan penarikan kesimpulan. Hasil penelitian menunjukkan bahwa nilai-nilai budaya yang terkandung dalam ritual bulangan londong sembangan suke barata adalah manuk yang melambangkan nilai etos kerja, ussembang suke barata yang mewakili nilai religius bambu yang ditebas oleh mina, dan kayunan londong sebagai personifikasi nilai patriotik pemimpin.

Kata kunci: nilai budaya, bulangan londong sembangan suke barata, masyarakat adat Toraja. 


\section{A. INTRODUCTION}

Toraja culture has undergone a drastic cultural change. Since long ago we have lived in a global village, therefore we have two types of cultural heritage that influence each other. The first is the cultural heritage of Toraja ancestors and each ethnic group in Indonesia which is hundreds of numbers (Sandarupa, 2014).

In the societal dimension, the Toraja people are so famous for their social and cultural traditions that are loaded with religious nuances, beauty, and the character of local wisdom that is maintained for generations from generation to generation (Baan \& Suyitno, 2020), held as a complete philosophy of life (Sudarsi, Taula'bi', \& Girik Allo, 2019), as a guide to determine attitudes, behaviors and work ethic for the community in religion, society, and nation (Rantetana, 2017). Thus it can be seen in the life of the Toraja people, that his life as a whole is bound by customs and culture (Wahyuningsih, 2018). It is developed based on the belief that becomes the motivation, namely the determination to live harmoniously and harmoniously, which at the same time becomes the purpose of the alliance concerned (Handayani, Ahimsa-Putra, \& Budiman, 2020). In the beliefs and lives of the Toraja people, society and individuals are governed by aluk sola pemali, namely aluk tallu oto'na and aluk a'pa' oto'na. Aluk tallu which include belief in Puang Matua, belief in gods, and to multiply puang. While aluk $a^{\prime} p a$ oto'na concerns social rules (Biringkanae, 2003; Indratno, 2016).

Toraja is one of the ethnic groups in South Sulawesi (Masitha Dewi, Gesrianto, \& Daeng Tata Raya, 2020; Guntara, Fatchan, \& Ruja, 2016) performs the unique culture especially for the funeral ceremony (Suriamihardja, 2006) and the thanksgiving ritual (Mustafa, 2018). Both of the two dimensions of ritual in Toraja are organized and ordered by "aluk" or custom (Surya, Rahman, \& Makka, 2017; Sandarupa, 2015). One of the lesoan aluk or rituals performed both on the activities of rambu tuka' and rambu solo' toraja is bulangan in londong or cockfighting (Santosa, Basuki, \& Puspita, 2019). In this study, researchers focused more on the bulangan londong held at the death ceremony (rambu solo') namely bulangan londong sembangan suke barata. Palayukan (2015), today some people still understand that the implementation of bulangan londong sembangan suke barata is part of $a d a^{\prime}$, aluk (custom) and is a legacy of ancestors that must be preserved.

The ritual of bulangan londong in the death ceremony is only given to them who is the highest social status or the Torajan leader. But not all the highest social status of Torajan is automatically celebrated by giving bulangan londong sembangan suke barata (Waterson, 1993). Those who hold the leader that chosen through "kombongan" or great deliberation and when he led the society, he served the community for prosperity and save them from danger. Besides the previous requirements, those who can be given the ritual of bulangan londong sembangan suke barata is the family who held the funeral ceremony in the rapasan sapu randanan type. The rapasan sapu randanan means the river's edge, this ritual sacrifices the number of buffaloes (Rahmita, 2018). Rapasan is the funeral ceremony held for the highest social status of Torajan (tana' bulaan). The number of buffaloes sacrificed from 24,30 , even more than 100. In Rapasan sapu randanan ritual, the family prepares the statue made of wood that resembles the deceased's face and body. Actually, the level of rapasan ritual is divided into three; rapasan diongan (lower requirements), rapasan sundun (complete/ top), and rapasan sapu randanan (river's edge) (Ranteallo, 2007; Ismail, 2019). The decision of someone can be given the bulangan londong ritual is through great deliberation and community recognition by bringing the cock when the death ceremony begins.

Unfortunately, these customs and cultures in their application are abused and not placed in their actual place. Culture is no longer placed as life management practiced in accountability relations in society. Bulangan 
Londong is implemented not on the actual customary rules. Community groups involve gambling in these activities so that it gives rise to negative values. Thus, the bulangan londong londong must be returned to the actual customary rules, so that the values of local toraja wisdom can be maintained and become a guide to people's lives in living life. Related to this have emerged different perceptions. On the one hand, some see it as part of lesson aluk that can only be carried out by adherents of the religion aluk sanda pitunna (Aluk Todolo) (Lestari, Soleha, Ibrahim, Ruwaedah, \& Roosihermiatie, 2012). On the other hand, some see it as a custom that can be carried out by community groups outside the beliefs of aluk todolo, although it is only held in certain circles or groups (A'ban, 2019).

The studies on the value in Toraja culture and bulangan londong sembangan suke barata rituals have been conducted by several researchers. Palayukan (2015) found that the implementation of bulangan londong in Toraja lately is no longer based on norms or prevailing Toraja customs. Meanwhile, indicators of gambling practices in a bulangan londong ritual when using valuables such as gold, silver, money, and so on are put in one place. Whoever comes out as the winner, is the one who deserves suke baratu (Prayogi \& Danial 2016).

Furthermore, in the bulangan londong sembangan suke barataphrase, the word "barata" means mourning. The word barata is different from the word baratu, baratu means a collection of stones, a bet collected by all participants (Manggau \& Jayadi, 2019). From this aspect baratu more meaning gambling because of risking objects. From the dimension of Toraja customs and culture, Tappi (2006) found that bulangan londong sembangan suke barata is a divine ritual and is an integral part of the aluk or ritual and culture of Toraja, according to the teachings of aluk todolo.

Meanwhile, related to Toraja cultural values, Sandarupa (2017) and Bahfiarti (2015) found the values in the oral literature of Toraja namely "malambu" or honesty, "misa' kada" or single voice, and the values of "kasiuluran" or brotherhood. Meanwhile, Pasande (2013) found that longko' culture as a result of the internalization of various understandings held firmly by the Toraja people, not only contains the value of honor, self-esteem, and shame but also other positive values in the form of spirit and work ethic. Kamalamburan (honesty) and carapace (harmony) are the values that are prioritized by the Toraja people. Longko' culture is especially relevant in relation to the nation's efforts to address the dangers of corruption through a cultural approach.

Patiung (2017) found that the application of Toraja cultural values in language learning at Toraja High School has built the values of kasiuluran (kinship), tengko situru' (togetherness), kabassaran (work ethic), sikamali' (love), kapapatonganan (religious), siri' (shame), and the value of umpangke' to mandadianna (child devotion to parents). Syarif, Hasriyanti, Fatchan, Astina, \& Sumarmi (2016) found the values of togetherness, and adhesive for the people in the Toraja death ceremony conversation. Ratnawati (2009) found hard-working and patient values in the folktale Toraja. Thus, in this study, the authors investigated the cultural values of the bulangan londong sembangan suke barata ritual of the indigenous people of Toraja, Indonesia.

In the context of today's Toraja society, Bulangan londong sembangan suke barata has been matched or even identified with cockfighting gambling. This brings negative consequences, namely decreased morals because what is revealed from these activities are chicken cockfighting gambling and other forms of gambling. It shows that the understanding and implementation of customs is no longer put on its portion and has not been responsible. Differences in perception and implementation of these activities have threatened the comfort and order of people's lives. At least it has caused confusion, tension, and even social conflict, especially when placed in the context of religious diversity and the relationship between religious law, 
positive law and customary law. Departing from the problem, the authors are interested to know the cultural values of the bulangan londong sembangan suke barata ritual of the indigenous people of Toraja, Indonesia.

\section{B. METHOD}

This study used Creswell qualitative method (2012). In collecting data in this study, researchers used research instruments, namely: Oral literary documents obtained from various sources such as libraries (digital and non-digital). Furthermore, in-depth interviews with: traditional Toraja figures and Toraja oralliterary speakers. Observation participant is assisted by filed note, recording device to document the results of interviews, pictures (photos) with a camera, and video capture with the help of handycam. This research was conducted in the North Toraja regency and Tana Toraja. The subjects of the study included: Traditional and cultural figures of Toraja, and speakers of Toraja oral literature.

In qualitative research as recommended by Miles and Huberman, data analysis includes three main steps: 1) data reduction, 2) data presentation, 3) conclusion drawing, and verification. These three steps are carried out continuously from the beginning. The three main things according to Milles and Huberman can be described as follows:

The stages of data analysis in this study can be explained through the process of data collection, data reduction, data presentation, and conclusion or verification as follows: 1) Data collection: this data collection was conducted in connection with data in the field, namely researchers conducting observations, interviews, and giving questionnaires to respondents in this study. 2) Data reduction: at this stage, researchers examined several data obtained from interview transcription, field notes, observations, and documentation data. All the data is analyzed and organized, namely by writing a summary, separating important data related to research problems with irrelevant data. Related to irrelevant data, researchers will still reanalyze if later researchers still need those data in data processing before drawing the conclusion. 3) Presentation of data: the presentation of data is a set of information that is composed and can draw a conclusion in taking an action. The form of presentation of data selected in this study is a narrative form with the purpose/expectation of each data that can not be separated from the background. 4) Drawing conclusions is a complete configuration activity. In accordance with the objectives to be achieved from the background as above, the analysis and withdrawal of conclusions are carried out. In this study, researchers re-corrected the results of the study and after the data is appropriate can then be drawn conclusions from each existing item.

\section{FINDINGS AND DISCUSSION}

Aluk is the teachings and rules of life as a belief that has been passed down since time immemorial. In the Toraja-Indonesia dictionary, compiled by Tammu and van der Veen (1972), aluk is defined as the thing of being devoted to God and God; traditional or religious ceremonies, customs; and behavior. Therefore, aluk can be understood as a belief, worship ceremonies according to the established manner based on the teachings of the religion concerned, customs and behavior as an expression of belief in daily life. Aluk is not only about belief, but it includes teachings, rites, and prohibitions or pemali (Kobong, 2000). Aluk also includes the rules of life or discipline of the cosmos both individually and with the environment. Aluk discussed in this section is Aluk todolo (kandian todolo), which is a term for the religion, tribe, beliefs, and rites of life of the Toraja people before the arrival of new religions such as Islam and Christianity.

According to the Toraja myth, everything in this world begins in the sky, including the origin of the ancestors of all 
beings. This world is a shadow of the world above or a duplicate of the celestial world. Aluk is set apart in heaven, therefore the aluk is divine. According to this belief, puang matua created the earth with all its contents including the rules used in his worship of the creator. From heaven, aluk is brought down with all its completeness to the earth by man (Tomanurun, Pangala Tondok). The aluk that governs the relations of the entire cosmos is complete and is mentioned in the expression Aluk Sanda Pitu (all seven, meaning complete and sufficient, nothing less).

The way of worship has also been established by the creator in the form of aluk through rites and pemali. It has also been determined that the sacrifices used in rituals are animals, plants, water, iron accompanied by praises and hymns (Biringkanae, 2003). This aluk was created by the gods and the gods faithfully followed it. The system of life of these gods was brought to earth and manifested in the daily life of man. The aluk is commonly called aluk sanda pitunna or aluk pitungsa'bu pitu ratu' pitungpulo pitu.

Aluk is a matter of dutiful to puang matua, the god and topuang. Aluk concerns the belief in whom it is believed, namely the teachings, ceremonies (rites), and prohibitions or bans. It also contains the rules of how man relates to the highest. The meaning of the word requires that aluk is not only a matter of belief alone but aluk includes teachings, rites, and prohibitions or pemali. All actions such as war, dance, eating, house building mating, processing rice fields, slaughtering animals, fighting feet are all tied with aluk. The deeds of the aluk regardless of the series of worships, then the deeds result in calamity. Because in religion, man has a relationship with the "highest spirit", called God, who creates and rules nature. Aluk himself is much feared and therefore should not be violated. Because of fear of the consequences of violations of aluk then people often do victims selfoffering (massuru'). Aluk has the power to guarantee life, aluk is a guarantee of sustainable living, providing peace of wellbeing but also can bring the danger of disease, disaster, curses if violated (Biringkanae, 2003).

One of the rituals (lesoan aluk) performed at the solo sign activity' Toraja is bulangan londong sembangan suke barata. Today some people still understand that the implementation of bulangan londong sembangan suke barata is part of $a d a^{\prime}$, aluk (custom) and is a legacy of ancestors that must be preserved. Bulangan londong is a ritual in the belief of "aluk todolo" or custom in the old belief of the Toraja people as a means to relate to something that is a myth which is something that is considered to have the power to save, animate, and give peace namely puang matua.Bulangan londong sembangan suke barata as one of the liturgical parts (lesoan alukna rambu solo') in rambu solo' can be interpreted as a rooster fight with the aim of reed chicken that fell into suke barata (pours) that had previously been cut (developed) by to minaa. Reed chicken inserted into bamboo or pouring is a symbol of the peak of purification of the dead (behind the pesungna) as well as a form of appreciation, the last respect of the dead for his services to guard, nurture and dare to make good decisions, and right as a community leader during their life.

Bulang is also defined as a leash on roosters, londong (rooster), sembangan (fla tter) once with tilt, suke (tube of bamboo), roofing; barata means mourning. The word barata is different from the word baratu, baratu means a collection of stones, a bet collected by all participants (Rita, 2000). The use of the word baratu in the sembangan suke baratu sentence more leads to the sense of cockfighting with betting objects, where betting objects such as gold, silver, money and so on are put in one place. Whoever comes out as the winner, is the one who deserves suke baratu (Manta, 2000). From this aspect baratu more meaning gambling because of risking objects.

In relation to aluk, bulangan londong has been used as a ritual in the belief of aluk 
todolo as a tool to relate to something that has been considered a myth that is considered to have the power and power to save, animate and give peace namely Puang Matua. Bulangan londong sembangan suke barata as one of the liturgical parts (lesoan alukna rambu solo') in rambu solo' can be interpreted as a rooster fight with the aim of reed chicken that fell into suke barata (pours) that had previously been cut (developed) by to minaa Reed chicken inserted into bamboo or pours is a symbol of the peak of purification of the dead (behind the pesungna).

Bulangan londong sembangan suke barata integrates in the aluk rambu solo', especially in the implementation of aluk barata kendek (dipuli misa' pitu lompo). Bulangan londongna lessoan barata, sembangan bulo lako toditolabonggalelena disonda kapayunganna dipatiran sangka', dilau'eran pangalukanna situru' pangraku'na. This means that the bulangan londong in the ceremony of grief is reserved only for the nobility or leaders. But not all nobles are automatically paraded. He must be a leader elected by deliberation (kombongan) and when he leads his attention is devoted to serving the welfare of the community and protecting his community from all dangers that come threatening. The determination that he should not be given the bulangan londong is through a communiqué agreement and public recognition by bringing the kayunan londong at the start of the ceremony of grief.

According to the mythology of Toraja bulangan londong especially related to the settlement of things (silondongan) begins (tigaronto') above the sky.

"That puang matua asked to build a house a'riri bonga ura'na. To build this house it takes pande petanga' (thinker), pandepaita (necrom en), pande manarang (smart person), and pande paliu' (supervisor). After the house of a'riri bonga posi' is done thanksgiving or mangrara banua and as a condition cut three kinds of animals or in tallu rarai (sacrifice of blood from 3 types of animals) namely chicken, pig, and buffalo" (Biringkanae, 2003).

The thanksgiving event also divided the social structure and position in the community (toe nene') to all citizens who attended. Some are determined to be Parengge', to Makaka, and some are determined to be slaves because they are late to the event.

"[...] He who will be a slave (la lumbang mendadi peosok ongan). But he objected, that how could he be appointed a slave while we were one blood, one flesh, we were brothers. So it was decided to resolve the issue with customary law (Petarian Pempitu Dao Langi'). Tampo sitetean, siukkunan, sibambangan, sipakoko, simimmi', sidemmeran padang, and the latter silondongan. But the one who has been designated as a slave remains defeated".

The dispute that occurred above the sky due to the division of positions and positions in the community is considered as the beginning of the emergence of Petarian Pempitu Dao Langi' (Toraja customary judiciary). Especially the solution of things with Silondongan road.

The ritual of bulangan londong in the death ceremony is only given to them who is the highest social status or the Torajan leader. But not all the highest social status of Torajan is automatically celebrated by giving bulangan londong sembangan suke barata (Waterson, 1993). Those who hold the leader that chosen through "kombongan" or great deliberation and when he led the society, he served the community for prosperity and save them from danger. Besides the previous requirements, those who can be given the ritual of bulangan londong sembangan suke barata are the family who held the funeral ceremony in the rapasan sapu randanan type. The rapasan sapu randanan means as the river's edge, this ritual sacrifices the number of buffaloes (Tsintjilonis, 2000). Rapasan is the funeral ceremony held for the highest social status of Torajan (tana' bulaan). The number of buffaloes sacrificed from 24, 30, 
even more than 100. Rapasan sapu randanan ritual is very unique, the family prepares the statue made of wood that resembles the deceased's face and body. The level of rapasan ritual is divided into three; rapasan diongan (lower requirements), rapasan sundun (complete/ top), and rapasan sapu randanan (river's edge) (Ranteallo, 2007; Ismail, 2019). The decision of someone can be given the bulangan londong ritual is through great deliberation and community recognition by bringing the cock when the death ceremony begins.

The values contained in bulangan londong sembangan suke barata found in this study are: manuk londong which symbolizes the value of work ethos, ussembang suke barata which represents the religious value of bamboo slashed by to minaa, and kayunan londong as the personification of the patriotic value of the leader.

\section{Manuk Londong: Symbol of The Value of Work Ethos}

For the Toraja people, "Manuk Londong"/ rooster has a variety of symbols. One of them is as a symbol of the value of work ethos. In the morning, the rooster's crow becomes an alarm to start work activities. All family members work hand in hand as farmers, ranchers, and other activities. They work until sunset. This is similarly conveyed by the respondent in this study, ELS, that, "It is the rooster that wakes the Toraja people in a resting place to start the activity until the chicken returns to its contest". Thus, chickens become an alarm for the activities of the Toraja people to start and finish their work every day. At the same time show ethos work Toraja people, ELS, "membuyapi manuk namane sule" or they will go home if the chicken is already contested".

One of the "lolo patuoan" or animal dimensions used in the ritual bulangan londong sembangan suke barata is "manuk londong" or rooster. In the socio-cultural aspect of Toraja, manuk londong symbolizes the value of ethos of the work of the Toraja people. In the morning, when the rooster crows then the Toraja human activity begins. Likewise, in the afternoon, when the chickens return to the "buyanna" or place of perch, then the activity is stopped, continued the next day, and they return home to rest. This is similar to that stated by Tappi (2006) that the rooster's crow awakens the man from the bed, reminding the human to start activities in the morning and stop by the time the chicken returns to its contest. Chickens welcome the morning rays to knit and move on with life for mankind. (Alfiah \& Supriyani, 2016) state that so important roosters give so many symbols for the life of the Toraja people that the rooster is also depicted in the traditional house of tongkonan which is set against the background of natural forces in the form of a series of curved lines that are interpreted as rooster feathers ("Londong" or Rooster). This motif symbolizes manliness, might, and wisdom.

The work ethos of the Toraja people is not only seen in their hometown, the hard work of Toraja people is also so famous overseas. Everyone who has Toraja blood has an obligation to bear the consequences of the cultural traditions in their hometown, so even though they are far from home, they still have a material obligation to the implementation of cultural traditions in their hometown. The spirit of close togetherness binds the brotherhood of the Tana Toraja tribe to make their children who are in the middle of being obliged to continue to send a number of materials as a payment of "debt" to families who carry out customary traditions. This closely binding cultural tradition and needing enough material make every tribe of Toraja Land has a spirit of hard work and a high work ethos in order to produce enough material to finance the cultural tradition. The income they get in overseas areas will be sent to their hometown in Toraja.

Toraja indigenous people, symbolically in the figure of the rooster 
gives the impression of the shape, attitude, and behavior of the rooster instinctively attached to each individual into a concept of personality that is intact as an exemplary social norm and behavior, such as: charismatic, knight, nurturing, disciplined, loyal, honest, and polite to achieve perfection in the life of a qualified man in the world and the hereafter. Based on this belief, there are two fundamental things that become the purpose of the Toraja people in working, namely to buy Puang and obtain blessings. Both of these things are a necessity in the world now and in the future, puya.

These two things are closely fused and inseparable. In relation to that, the Torajas knew no separation between spiritual and temporal. Each work (which corresponds to the aluk) has a religious connotation. Membali Puang is a situation when a deceased person returns to become a god when the rites of his death are perfect (behind the pesungna). Solo sign ceremony' is a rite to transition one from world life to the mystical nature (poetic). The rites of death require so many sacrifices/offerings because they go through several ceremonial processes, and take a long time. For the ceremony, it takes sacrifices and foodstuffs, and costs for the people present in the ceremony (rites).

Therefore property or wealth is important and pursued by the Toraja people during his life. Property/wealth determines the slow pace of a person to buy puang. It can happen that a person does not make a mistake of his own during life or the inability of his relatives to complete the rites that become a condition for to membali puang. For the sake of his safety, the Toraja people were able to live a simple life even languishing, working hard, diligently, and living frugally, this lifestyle was applied to gather provisions for life in puya. Work and work influence and determine the "heavenly" life of the Toraja people. Thus safety motivation underlies work behavior and plays an important role in the work ethic of the
Toraja people. Safety motivation is closely related to other work motivations, namely to get blessings from puang matua and to membali puang. The work obtained in addition to meeting the needs of life is partly used as an offering in rites. The rites cover all human activities from birth to death.

Every effort, activity, and stage of life has its rites. The main purpose of the implementation of these rites is to glorify God. But actually, the basic motivation behind the purpose of praising God is the desire to get blessings. Offerings are sought to please puang matua and to membali puang to bestow their blessings on the worshiping man or the family left behind. The wealth is used as a means to persuade puang matua and the gods (to membali puang) to increase property and live a happy and prosperous life. Therefore wealth is often identified with happiness and well-being both in this world and in the world there. All offerings in aluk rambu tuka' addressed to puang matua and all sacrifices in the solo sign' to the ancestors, will not be in vain but will be a channel of blessings that can bring inner birth well-being. But the most important motivation of the other motivations of the life and work of the Toraja people is safety.

Work in understanding the Toraja people when connected with safety is a means to buy safety. One's salvation is determined by the fewest savings he accumulates while on earth. Work determines the safety of the Toraja people. Positively the practice of work in the life of the Toraja people contains the view that there are no joints and corners of human life that are independent of faith (belief) thus no activity of human life is independent of the observation of God (puang matua); this world is part of later (heavenly) life so that all human efforts are focused on salvation. This can make man aware of God's presence in every activity and work. The religious motivation 
behind bulangan londong sembangan suke barata ritual is safety and leadership.

For the sake of his safety, the Toraja people were able to live a simple life even languishing, working hard, diligently, and living frugally, this lifestyle was applied to gather provisions for life in Puya. Work and work influence and determine the "heavenly" life of the Toraja people. Thus safety motivation underlies work behavior and plays an important role in the work ethic of the Toraja people. Safety motivation is closely related to other work motivations, namely to get blessings from puang matua and to membali puang. The work obtained in addition to meeting the needs of life, partly used as an offering in rites. The rites cover all human activities from birth to death. Every effort, activity, and stage of life has its rites. The main purpose of the implementation of these rites is to glorify God. But actually, the basic motivation behind the purpose of praising God is the desire to get blessings. Offerings are sought to please puang matua and to membali puang to bestow their blessings on the worshiping man or the family left behind. The wealth is used as a means to persuade puang matua and the gods (to membali puang) to increase property and live a happy and prosperous life. Therefore wealth is often identified with happiness and well-being both in this world and in the world there. All offerings in aluk rambu tuka' addressed to puang matua and all sacrifices in the rambu solo' to the ancestors, will not be in vain but will be a channel of blessings that can bring inner birth well-being. But the most basic motivation of the other motivations of the life and work of the Toraja people is safety.

\section{Ussembang Suke Barata: Religious Value in Slashed Bamboo}

According to ELS, "ussembang suke barata" or bamboo cutting is carried out by a "to minaa" or Toraja literary expert/ pastor of the original Toraja religion (aluk todolo/ old belief)". Ussembang suke is performed before the ritual of "ma'palao" begins. Ma'palao procession is one of a series of rambu solo' rituals (ceremony of grief) Toraja, this procession is the activity of parade the body of the "tongkonan" or traditional house Toraja to the location of "liang" or grave.

The stage of "ussembang suke barata" begins with taking bamboo and then a "to minaa" cuts it into a "suke" similar to a traditional Toraja drink place. The tool for cutting it is a traditional Toraja machete called "la'bo' todolo". La'bo' todolo is believed to be a sign as well as a decision on whether this ritual can be performed or not. Meanwhile, to minaa was present and performed her duties as a priest during the procession. When "to mina" slashes the suke once, it means that the procession of bulangan londong sembangan suke barata has been blessed and valid to be carried out.

The piece of "suke" or bamboo is then taken by to mina to the location of the implementation of the rambu solo'. While the suke is carried by to mina, a group of dancers welcome. The dance used is dance to ma'randing. This dance depicts the war situation in ancient times. This dance is also a sign that the deceased is a tough and brave leader. Then, the "suke" is cut into pieces in a barn or "reed". After being cut into pieces, it is continued by carving and arranging the "suke" like a necklace.

"Suke" which has been arranged like a necklace is prepared as a place to unite chicken feathers that fall out when pitted. The purpose of collecting chicken feathers in the "suke" is as a supply of spirits entering the "puya" or place where the spirits dwell forever (heaven). The result of collecting chicken feathers in the "suke" is placed in two different places: in tonkonan / alang, and at the burial site. This is a sign and a warning that the family at the site once performed the ritual of "bulangan londong sembangan suke 
barata" in memory and respect for the leader who has died.

The Toraja people in the traditional procession of old beliefs in this case the ritual of bulangan londong sembangan suke barata shows a very high religious value. The stages in each ritual are always preceded by "singgi"" or prayer so that each activity process can run well, smoothly, and avoid danger.

In the procession of the implementation of bulangan londong sembangan suke barata, there is one activity carried out by "to mina" or Toraja literary experts/pastors of the original religion of Toraja (aluk todolo / old beliefs of the Toraja people) namely the procession Ussembang suke barata. Ussembang suke barata represents the religious value of bamboo slashed by to mina. The stage of "ussembang suke barata" begins with taking bamboo and then a "to minaa" cuts it into a "suke" similar to a traditional Toraja drink place. The tool for cutting it is a traditional Toraja machete called "la'bo' todolo". La'bo' todolo is believed to be a sign as well as a decision on whether this ritual can be performed or not. Meanwhile, minaa was present and performed her duties as a priest during the procession. When "to mina" slashes the suke once, it means that the procession of bulangan londong sembangan suke barata has been blessed and valid to be carried out. This is similar to that stated by (Palayukan, 2015) that bulangan londong sembangan suke barata is a hereditary custom of the Toraja people who have a high spiritual value, and this ritual is not indiscriminately carried out, only a solo sign party' at the level of rapasan sapu randanan can carry it out. In addition, the procession is closely related to the religious belief that a nobleman who died while in puya was still served by a servant so that in the realm of spirit they did not become slaves. Chickens are sacrificed after being pitted into provisions, while they enter the spirit realm which for the
Toraja people is called "puya". The chicken will be a requirement for a leader to enter into the spirit world and become a to membali puang (Tappi, 2006).

The ritual of bulangan londong in the death ceremony is only given to them who is the highest social status or the Torajan leader. But not all the highest social status of Torajan automatically celebrated by giving bulangan londong sembangan suke barata (Waterson, 1993). Those who hold the leader that chosen through "kombongan" or great deliberation and when he led the society, he served the community for prosperity and save them from danger. Besides the previous requirements, those who can be given the ritual of bulangan londong sembangan suke barata are the family who held the funeral ceremony in the rapasan sapu randanan type. The rapasan sapu randanan means the river's edge, this ritual sacrifices the number of buffaloes (Tsintjilonis, 2000). Rapasan is the funeral ceremony held for the highest social status of Torajan (tana' bulaan). The number of buffaloes sacrificed from 24, 30, even more than 100. Rapasan sapu randanan ritual is very unique, the family prepares the statue made of wood that resembles the deceased' face and body. Actually, the level of rapasan ritual is divided into three; Rapasan diongan (lower requirements), rapasan sundun (complete/ top), and rapasan sapu randanan (river's edge) (Ranteallo, 2007; Ismail, 2019). The decision of someone can be given the bulangan londong ritual is through great deliberation and community recognition by bringing the cock when the death ceremony begins.

\section{Kayunan Londong: Personification of The Leader's Patriotism}

The ritual of the bulangan londong sembangan suke barata in the rambu solo' procession is carried out under certain conditions. First, the determination of whether a deceased person is said to be worthy of a bulangan londong sembangan 
suke barata is through "kombongan" activities or deliberations. At this deliberation, the other leaders invited the whole community to attend and give a decision. To determine whether or not someone is given bulangan londong sembangan suke barata was determined by deliberations, in which another leader invited all communities to be involved in attending and making decisions in the commencement.

The

deliberations

called kombongan are the unifying pillars of the community. The presence of the community in the kombongan rights. The agreement through the commencement can change the existing rules, remove and replace them with the new rules. Kombongan has absolute power as a decision-maker called Untesse Batu mapipang (can break rock). Therefore, each kombongan needs to be sacrificed by chickens and hanging pigs the magnitude and value of the decisions to be taken, in such a way, his desperation is very binding on members of the community. With the ritual event, the decision of kombongan can be said to have value as a covenant (bass) involving the god who is believed. It is the duty of other leaders to secure the decision of the commission. The point is that the decision through kombongan reveals the public's recognition of the quality of leadership of the dead.

Second, the substance of the requirement is that only those who have performed a major task according to Toraja customs are given this ritual. ELS explains that those who have carried out the tongkonan philosophy are entitled, "bida, sugi', manarang sia kinaa, na barani".

"Bida" means descendants of Toraja nobles. In Toraja mythology, "Bida" is to manurun $d i$ langi'or nobleman who descends from the sky. The degree they obtained has different terms, depending on the area residents in the Toraja tribe. According to ELS, some are given the title "puang, ma'dika, ambe', tedong pariu, anak topatalo, and others". Those who become descendants of noble "Bida" do not immediately become a ruler or leader, he must pass the time to gain experience of wisdom/intelligence possessed and supported by "kasugiran" or wealth. Sugi'means to have abundant world wealth, manarang sia kinaa means smart and generous, and barani means courage in nurturing and protecting its people and dare to make decisions under any circumstances for the good of the people.

The leader of the Toraja people must be "sugi" or rich. ELS reveals that "Representation of "kasugiran" or wealth of Toraja people is in "tallu lolona" philosophy or three pillars of life of Toraja people, "lolo tau" or human, "lolo patuan" or animal, and "lolo tananan" or plants. In lolo tau philosophy, for Toraja people in this perspective, many children become a measure of wealth. ELS explains that "It is the child who lifts the dignity and dignity of the family through "tongkon" or sitting with the rest of the family in customary activities or assisting the family in urrundunan sara' or participating in traditional ritual activities, rambu tuka' (joy rituals) and rambu solo' (rituals of sorrow).

Hymn lolo tau enshrined in oral literature Toraja namely, "kasalle male melendong, lobo' male meburinti, sangtontian pelendongna, sangburia' peburintinna". [Someday, grow up, go catch the eel, the adult catches the rice parrot, one bond catches the eel, one basket of the rice kareo bird catches]. This hymn is spoken for boys so that when they grow up they will be able to find eels/fish and birds in the rice fields as food. As for girls, also prayed to be able to find foodstuffs in the form of fish, said hymns like this, "kasalle male meurang, lobo' male mekabumbu', sangseran peurangna, sangbakku' pekabumbu'na" [if big later, go looking for shrimp, as an adult go looking for lead fish, hopefully, a lot of shrimp catches, a basket of lead head fish]. These 
two hymns are said in the hope that one day when the children in the family grow up to work hard to collect materials (treasures) for the needs of their lives.

On lolo patuan, buffalo, pork, and chicken are a measure of the wealth of the Toraja people. A person who initially raised chickens was tried again to raise pigs and was further improved by raising buffalo. The pet buffaloes were exchanged for rice fields or exchanged temporarily for other people's rice fields. Meanwhile, rice becomes one of the most valuable lolo patuan. Toraja people who have a lot of rice fields are stored in barns "alang". Alang lined up containing rice became a sign of "kasugiran" or wealth of the Toraja people.

In addition to the aforementioned conditions, the one entitled to be given a month by suke barata according to the ELS is a "rambu solo" in the state of "rapasan sapu randanan". Rapasan sapu randanan translated as fiber with the riverbank, this ritual sacrifices a number of buffalo. The range of buffalo sacrifices starts from 24, 30, even above 100 heads. Rapasan sapu randanan ritual is so unique because, in this procession, the family prepares "tau-tau" or wooden statue resembling the face and body shape of one of the deceased families (which is temporarily declared customarily).

Thus, in "aluk" or Toraja custom, the element of courage and toughness of a leader is highly appreciated. Thus, the implementation of the bulangan londong sembangan suke barata ritual aims to honor the deceased leader for his services while still alive in thinking about the territory he leads and upholding justice, truth, and doing good in accordance with "aluk" or customs and "pemali" or norms.

In the life of the Toraja people, that their life as a whole is bound by customs and culture (Wahyuningsih, 2018). It is developed based on the belief that becomes the motivation, namely the determination to live harmoniously and harmoniously, which at the same time becomes the purpose of the alliance concerned (Handayani, Ahimsa-Putra, \& Budiman, 2020). In the beliefs and lives of the Toraja people, society and individuals are governed byaluk sola pemali, namely, aluk tallu oto'na and aluk a'pa' oto'na. Aluk tallu oto'na is a rule of a man with his beliefs which include belief in Puang Matua, belief in gods, and to multiply puang. While aluk $a^{\prime} p a^{\prime}$ oto'na concerns social rules (Biringkanae, 2003; Indratno, 2016). It is based on "aluk" or Toraja custom that the element of courage and toughness of a leader is highly appreciated. Thus, the implementation of the bulangan londong sembangan suke barata ritual aims to honor the deceased leader for his services while still alive in thinking about the territory he leads and upholding justice, truth, and doing good in accordance with "aluk" or customs and "pemali" or norms. This is related to (Tappi, 2006) that bulangan Londong Sembangan Suke Barata is a magical ritual that integrates individual personalities in a continuous cycle as an explanation of individual attitudes/behaviors and instinctive impressions in every Torajan, especially among leaders and nobles. In line with Alfiah and Supriyani (2016) that roosters give symbols for the life of the Toraja people such as manliness, might, and wisdom.

In rites aluk todolo, chicken has the meaning of offerings both in the feast of rambu tuka' and in the ceremony of rambu solo', moreover at the kaperokan event (aluk sumpu lolokna, ditallu rarai namely the blood of chickens, pigs, and buffalo). Similarly, in the sign solo' when meaa (ma'peliang) chicken is taken to the grave (to' liang) and pitted but without betting as the completeness of the ceremony in the hope that the chicken will bring the safety of the soul of the dead. (... kengku manukna lapendek londongna tulang didi' angku tiaranko sau' tondok pong lalondong ...). A solo ceremony for a leader who qualifies for the leadership of tallu bakaa is said to 
be sundun (complete) when performed by bulangan londong sembangan suke barata ritual. This ritual is a prerequisite for puya guards, puang lalondong, to allow him to enter the spirit world.

The belief of salvation as above is contained also in the myth of la pandek and tulangdidi'. The spiritual meaning of la pandek's living behavior and beloved chicken, lies in his interspersed relationship with his master: the live chicken of the broiler caterpillar tulangdidi', and vice versa tulangdidi' revived because of the services of chickens. From the understanding that man is applied in the figure of a rooster (londong) this then develops far with special understandings symbolically, cultured from the impression of the shape, attitude, and behavior of roosters instinctively attached to each individual into a concept of a complete personality as an exemplary social norm and behavior, such as; charismatic, knighted, nurturing, disciplining, loyal, honest, and polite to achieve perfection in the life of a man who is qualified in the world and the hereafter. Thus the belief that exists in the implementation of the bulangan londong sembangan suke barata is concerned about the issue of human safety after death. While the myth is to make puang and kayunan londong to puya. This understanding is also inseparable from myths about chicken la pandek tulangdidi.

The ritual of bulangan londong sembangan suke barata has a dual purpose or function. On the one hand, he intended to celebrate death as a path to the upper realm. In other words, this ritual serves as the initiation of lifting a person (the dead) to a higher existence. On the other hand, this ritual also serves educationally and transformatively. This means that in this ritual participants communicate and absorb certain values about leadership, about what should be upheld in society. It can also be said that this ritual is intended to pay homage to the dead. In this way, the participants of the ritual at the same time expressed their intention to respect and uphold the philosophy of leadership that has been implemented by the retired leader.

\section{CONCLUSION}

Based on the results of this study, it can be concluded that the cultural values contained in the ritual of bulangan londong sembangan suke barata are manuk londong which symbolizes the value of work ethos, ussembang suke barata which represents the religious value of bamboo slashed by to minaa, and kayunan londong as the personification of the patriotic value of the leader.

Based on the findings of cultural value contained in the Ritual of bulangan sembangan suke barata in this study, the researchers considered it important to maintain the ritual of bulangan sembangan suke barata in the procession of rambu solo' Toraja in accordance with the "aluk" or customs prevailing in Toraja. The cultural value found in this study is so essential in maintaining the character of the kingdom that upholds the value of work ethic, religion, and patriotism in public life.

In order for the cultural value in this ritual to be more interpreted and imbued by the Toraja people and known to the world, it is necessary for the next researcher to develop teaching materials based on Toraja cultural values for the development of the character of Toraja learners.

\section{REFERENCES}

A'ban, R. (2019). Nilai Sosial dalam Cerita Rakyat Toraja Seredukung (Suatu Tinjauan Sosiologi Sastra). (Skripsi), Universitas Muhammadiyah Makassar, Makassar.

Alfiah, A., \& Supriyani, E. (2016). Perubahan Bentuk Rumah Adat Tongkonan Tana Toraja Berdasarkan Pendapat Teori Lesesau. Teknosains: Media Informasi Sains dan Teknologi, 10(2), 183-196. https://doi.org/10.24252/TEKNOSAINS. V10I2.1899 
Baan, A., \& Suyitno, I. (2020). Cultural Representation of Toraja Ethnic on The Use of Vocabulary In Singgi' Speech. Litera, 19(2), 228-246. https://doi.org/10.21831/ltr.v19i2.32074

Bahfiarti, T. (2015). Cultivation Cultural Values Toraja Parents and Children Through Family Communication In Makassar City. KRITIS: Jurnal Ilmu Sosial dan Ilmu Politik Universitas Hasanuddin, 1(2), 209-218.

Creswell, J. W. (2012). Educational Research: Planning, Conducting, and Evaluating Quantitative and Qualitative Research. Boston: Pearson Education, Inc.

Guntara, F., Fatchan, A., \& Ruja, I. N. (2016). Kajian Sosial-Budaya Rambu Solo' dalam Pembentukan Karakter Peserta Didik. Jurnal Pendidikan: Teori, Penelitian, dan Pengembangan, 1(2), 154-158.

Handayani, R., Ahimsa-Putra, H. S., \& Budiman, C. (2020). Out of Crisis: Maintaining Hegemony through Rambu Solo Ritual in Toraja. International Journal of Indonesian Society and Culture, 12(2), 246-258. https://doi.org/10.15294/komunitas.v12i2 .23014

Indratno, I. (2016). Silau'na Tongkonan Sebagai Sebuah Realitas Tondok. Ethos Jurnal Penelitian dan Pengabdian Masyarakat, 4(1), 75-84.

Ismail, R. (2019). Ritual Kematian dalam Agama Asli Toraja "Aluk To dolo" (Studi atas Upacara Kematian Rambu Solok). Religi, 15(1), 87-106.

Lestari, W., Soleha, M., Ibrahim, I., Ruwaedah, \& Roosihermiatie, B. (2012). Etnik Toraja Sa'dan Desa Sa'dan Malimbong, Kecamatan Sa'dan Kabupaten Toraja Utara, Provinsi Sulawesi Selatan. In Etnografi Kesehatan Ibu dan Anak. Surabaya: Badan Penelitian dan Pengembangan Kesehatan, Kementerian Kesehatan RI.

Mackey, Alison, and Gass, M., S. (2005). Second Language Research: Methodology and Design. London: Lawrence Erlbaum Associates, Inc.
Manggau, A., \& Jayadi, K. (2019). Karume Tradition in Toraja Tribe, South Sulawesi. Paper presented at the The 1st International Conference on Education Social Sciences and Humanities (ICESSHum 2019).

Masitha Dewi, A., Gesrianto, J., \& Daeng Tata Raya, J. (2020). Ethnosemantics Study Of Lexicon "Kuburan" In The Toraja People. Retorika: Jurnal Bahasa, Sastra, dan Pengajarannya, 13(2). https://doi.org/10.26858/retorika.v13i2.1 3804

Mustafa. (2018). Mitos Sangbidang: Rasionalisasi dalam Sastra Lisan Toraja. Jurnal Al-Qalam, 24(2), 307-318.

Palayukan, M. (2015). Peran Pemerintah Daerah Tana Toraja Dalam Menanggulangi Perjudian Bulangan Londong (Sabungayam) pada Upacara Kematian di Tana Toraja. Universitas Atma Jaya Yogyakarta.

Pasande, S. (2013). Budaya Longko' Toraja dalam Perspektif Etika Lawrence Kohlberg. Jurnal Filsafat, 23(2), 117133.

Patiung, D. (2017). Budaya Toraja dalam Pembelajaran Bahasa Indonesia. Jurnal Idaarah, 1(1), 121-132.

Prayogi, R., \& Danial , E. (2016). Pergeseran Nilai-Nilai Budaya Pada Suku Bonai Sebagai Civic Culture di Kecamatan Bonai Darussalam Kabupaten Rokan Hulu Provinsi Riau. Humanika, 23(1), 61-79.

Rahmita, A. (2018). Analsis pola Interaksi Edukatf Bernuansa Kearifan Lokal dalam Pembelajaran Ekonomi Kelas X di SMA Negeri 6 Toraja Utara. Skripsi, Universitas Negeri Makassar, Makassar.

Ranteallo, I. C. (2007). Pemakaman Ritual Mantunu Dalam Upacara Pemakaman Rambu Solo' (Studi Kasus Tentang Pemakaman Ritual Mantunu Dalam Upacara Pemakaman Rambu Solo' Tingkat Rapasan Sapu Randanan di Tongkonan Buntu Kalambe'. Universitas Gadjah Mada.

Rantetana, M. (2017). OPINI: Falsafah Tallu Lolona Kekuatan Budaya Toraja; Masa 
Lalu, Sekarang dan Masa Datang Kareba Toraja. Retrieved November 23, 2019, from Kareba Toraja website: https://www.karebatoraja.com/opinifalsafah-tallu-lolona-kekuatan-budayatoraja-masa-lalu-sekarang-dan-masadatang/

Ratnawati. (2009). Nilai Budaya dalam Cerita Rakyat Toraja. Mabasan, 3(2), 48-65.

Sandarupa, S. (2014). Kebudayaan Toraja Modal Bangsa, Milik Dunia. Sosiohumaniora, 16(1), 1-9.

Sandarupa, S. (2015). Glokalisasi SpasioTemporal dalam Agama Aluk To Dolo Oleh Agama Kristen di Toraja. Sosiohumaniora, $\quad 17(1), \quad 86$. https://doi.org/10.24198/sosiohumaniora. v17i1.5677

Sandarupa, S. (2017). "The Voice of a Child": Constructing a Moral Community through Retteng Poetic Argumentation. Toraja. Archipel, (91), 231-258. https://doi.org/10.4000/archipel.316

Santosa, A. B., Basuki, Y., \& Puspita, A. M. I. (2019). The effectiveness of Local Wisdom-Based Teaching Materials in Enhancing Creative Writing Skills of Elementary School Students. JELTL Journal of English Language Teaching and Linguistics, 4(3), 349-359.

Sudarsi, E. T., Taula'bi', N., \& Girik Allo, M. D. (2019). Filosofi Tallu Lolona dalam Himne Passomba Tedong (Etnografi Kearifan Lokal Toraja) [The Philosophy of Tallu Lolona in the Hymns of Passomba Tedong (Ethnography of Torajan Local Wisdom)]. Sawerigading, 25(2), 61. https://doi.org/10.26499/sawer.v25i2.666

Suriamihardja, D. A. (2006). Reaping Wisdom From The Teaching of Aluk Todolo for Environmental Management. The International Symposium: Crossing Disciplinary Boundaries and ReVisioning Area Studies: Perspective from Asia and Africa, from 9th to 13th November.

Surya, W., Rahman, F., \& Makka, M. (2017). Folktale from England to Toraja. Imperial Journal of Interdisciplinary Research (IJIR), 3(7), 1-5.
Syarif, E., Hasriyanti, Fatchan, A., Astina, K., \& Sumarmi. (2016). Conservation Values of Local Wisdom Traditional Ceremony Rambu Solo Toraja's Tribe South Sulawesi as Efforts The Establishment of Character Education. EFL Journal, 1(1), 17-23.

Tappi, S., R. (2006). Bulangan Londong Sembangan Suke Barata: Sebuah Tinjauan Teologis-Sosiologis Tentang Bulangan Londong Sembangan Suke Barata. Sekolah Tinggi Agama Kristen Negeri Toraja.

Wahyuningsih, D. (2018). Representasi Ritual Upacara Kematian Adat Suku Toraja dalam Program Dokumenter Indonesia Bagus Net TV Episode Toraja. Ejournal Ilmu Komunikasi, 6(1), 68-82.

Waterson, R. (1993). Taking The Place of Sorrow: The Dynamics of Mortuary Rites Among The Sa'dan Toraja. JSTOR, 21(2), 73-96. 
Patanjala, ISSN 2085-9937 (print), ISSN: 2598-1242 (online) 